\title{
血圧基準値の科学的根拠：高血圧治療ガイドライン 2014
}

\author{
滋賀医科大学社会医学講座公衆衛生学部門 教授 \\ アジア疫学研究センター長
}

三浦克之

多くの人口ベースの疫学調査において明らかなように人間集団の血圧值の分布はほぼ正規分布を示 し、正常血圧者と高血圧者の二峰性の分布を示すわけではない。また、肥満度（BMI）や血清コレス テロールなどと同様、集団における血圧の分布は、地域によって大きく異なりまた時代によって大き く変動するものであり、広い意味で集団の栄養状態を示す生体指標（バイオマーカー）と言える。

一方で、成人の血圧值はその後の循環器疾患リスク（脳卒中と心疾患の発症や死亡）と強い関連を 示すことが国内外の多くの疫学研究（前向きコホート研究）で明らかにされ、確立した循環器疾患の 「危険因子」となっている。関連は、血圧の低い方から高い方に向けて連続的・対数直線的な量・反応 関係を示し、閯值は認められない。したがって、「高血圧」の定義は人為的なものであり、また、コホー 卜研究で明らかになった将来の循環器疾患リスクの高さによって決定されている。

以上の観点からすれば、集団（例えば現時点の日本人）の血圧值の分布する範囲によって「正常值」 を決めることはできない。例えば、肥満が蔓延する現在の米国の BMI の分布、あるいは脳卒中が蔓延 した1960年代のわが国の血圧值の分布は、集団全体が好ましくない状態（sick population）にあり、多 くの人が分布する範囲を「基準值」とはできない。

国際的に見ると、1999年以前の WHO は160/95 mmHg 以上を「高血圧」と定義したが、その後高血 圧の定義は低い方にシフトし、現在ほぼ世界共通に140/90 mmHg 以上が「高血圧」と定義されている。 現在、日本高血圧学会や欧州高血圧学会の高血圧治療ガイドラインでは、「至適血圧 (optimal)」「正 常血圧 (normal)」「正常高值血圧 (high-normal)」「高血圧 (hypertension)」という分類が用いら れている。「高血圧」はさらに「I 度」「II 度」「III 度」に分類されている。また、日本高血圧学会ガ イドライン2014年版では「至適血圧」「正常血圧」「正常高值血圧」をまとめて「正常域血圧（normalrange）」と名付けた。米国では2003年の米国合同委員会第 7 次報告（JNC7）以降、従来の「至適血 圧」を「正常血圧」とし、従来の「正常血圧」および「正常高值血圧」の部分は「高血圧前症（prehypertension)」としており、「正常血圧」の範囲がさらに低い值に設定されたが、日本や欧州ではこの 分類は採用していない。

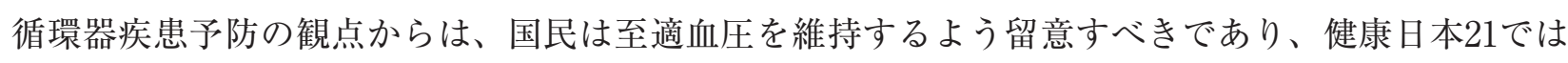
国民全体の収縮期血圧平均值の $4 \mathrm{mmHg}$ 低下を目標としている。「高血圧」の基準は、即、薬物治療開 始の基準ではない。至適血圧を超える全ての人に、まず生活習慣修正による血圧低下を促すための基 準であることも確認したい。

\section{【略歴】}

1988年 金沢大学医学部卒業

1993年 金沢大学大学院医学研究科修了

2002年 金沢医科大学公衆衛生学教室助教授 
2008年 滋賀医科大学社会医学講座准教授

2009年 滋賀医科大学社会医学講座公衆衛生学部門教授

2013年＼cjkstart滋賀医科大学アジア疫学研究センター長（併任）

\section{【主な所属学会】}

日本疫学会理事、日本循環器予防学会理事、日本高血圧学会幹事・編集委員、

日本公衆衛生学会評議員、日本循環器学会社員、日本動脈硬化学会評議員、

日本栄養改善学会評議員、日本衛生学会評議員 